\title{
Artikel
}

\section{De toepassing van de klachtplicht bezien vanuit het Wetsvoorstel kwaliteitsborging voor het bouwen}

\author{
Prof. mr. S. van Gulijk*
}

\section{Inleiding}

Over de voorgestelde Wet kwaliteitsborging voor het bouwen $2016(\mathrm{Wkb})$ is de afgelopen jaren al veel geschreven. Tot nu toe is in de literatuur over het wetsvoorstel vooral de aandacht gevestigd op de grote publiekrechtelijke wijzigingen die het wetsvoorstel meebrengt, ${ }^{1}$ de privatiseringsslag van de overheid meer in het algemeen, ${ }^{2}$ en de veranderingen in de aansprakelijkheidspositie van de aannemer ten opzichte van de (consument-)opdrachtgever. ${ }^{3}$ De voorgestelde privaat-

Prof. mr. S. van Gulijk is hoogleraar privaatrecht, bijzondere overeenkomsten, aan de Tilburg Law School.

1. Bijv. wijzigingen in de Woningwet en de Wabo. Zie daarvoor o.m. O. Laan \& M.P. Terwindt, Private kwaliteitsborging: kans of kruis?, TBR 2014/116, p. 619-629; P.M.J. de Haan \& H.C.W.M. Moesker, De risicobeoordeling bij de vergunningaanvraag Wkb, TBR 2017/92, p. 576-585; P.M.J. de Haan, De voorgestelde wijzigingen in de preventieve en de repressieve toetsing aan bouwtechnische voorschriften, TBR 2016/97, p. 507-516.

2. Zie o.m. S. van Gulijk \& A.R. Neerhof, Consultatiewetsvoorstel Kwaliteitsborging voor het bouwen (2014) - Laat verwachtingen geen bron voor teleurstellingen zijn, NJB 2015/454, p. 552-559; S. van Gulijk \& A.R. Neerhof, Constructieve veiligheid: een onderzoek naar communicatie en borging in bouwprocessen. Voorkomen is beter dan genezen (Preadviezen van de Vereniging voor Bouwrecht nr. 42), Amsterdam: WEKA Uitgeverij 2014; H.P.C.W. Strang, Toezicht en coördinatie in het bouwproces (diss. TU Delft), Den Haag: Instituut voor Bouwrecht 2018.

3. Zie o.m. M.A.B. Chao-Duivis, Geschilbeslechting bij kwaliteitsborging voor het bouwen. Een verkennend tweeluik. Het privaatrechtelijk kader, TBR 2016/7, p. 611-613; E.M. Bruggeman, De privaatrechtelijke aspecten van het wetsvoorstel Kwaliteitsborging voor het Bouwen (Deel II), TBR 2016/92, p. 590-598. rechtelijke wijzigingen die zien op de aansprakelijkheid van de aannemer na oplevering (art. 7:758 lid 3 Burgerlijk Wetboek (BW)) zijn ook van invloed op de toepassing van de klachtplicht in de bouwpraktijk. De algemene regeling van de klachtplicht is neergelegd in artikel 6:89 $\mathrm{BW}$. In artikel 7:23 $\mathrm{BW}$ is de klachtplicht verder uitgewerkt voor de koopovereenkomst. Voor de aannemingsovereenkomst geeft artikel 7:758 lid $3 \mathrm{BW}$ een nadere regeling van de klachtplicht. De toepassing van de klachtplicht die volgt uit de artikelen 6:89 en 7:23 BW heeft de afgelopen jaren veel aandacht gekregen als gevolg van het feit dat de juridische kaders door de rechtspraak zijn aangescherpt. ${ }^{4}$ In de bouwsector is de klachtplicht met name belangrijk waar het zogenoemde verborgen gebreken betreft, gebreken die bij oplevering van een bouwwerk niet zijn ontdekt door de opdrachtgever. Zowel in het Burgerlijk Wetboek als in aanvullende voorwaarden zijn verschillende regels opgenomen in afwijking van of in aanvulling op de klachtplicht uit artikel 6:89 BW. Zie onder meer artikel 7:758 lid 3 BW, artikel 7:761 BW en de procesrechtelijke vervaltermijnen die zijn opgenomen in de meest gebruikte algemene voorwaarden voor de aanneming van werk, de Uniforme Administratieve Voorwaarden voor de uitvoering van werken en technische installatiewerken 2012 (UAV 2012). Als gevolg van het genoemde wetsvoorstel wordt de klachtplicht uit artikel 6:89 BW des te belangrijker voor de bouwpraktijk. Bovendien, wanneer het gaat om consumenten-opdrachtgevers zijn de UAV 2012 in strijd met het dwingende karakter van het voorgestelde

4. O.m. in de zogenoemde 8 februari-arresten, waaronder HR 8 februari 2013, ECLI:NL:HR:2013:BY4600, NJ 2014/497. Zie hierna uitgebreid par. 2. 
lid 4. Professionele opdrachtgevers die onder vigeur van de UAV 2012 willen contracteren, zullen in de aannemingsovereenkomst een afwijkende regeling moeten opnemen.

In dit artikel zal ik de vraag beantwoorden welke gevolgen de voorgestelde Wet kwaliteitsborging voor het bouwen 2016 heeft voor de toepassing van de klachtplicht en genoemde verjarings- en vervaltermijnen in de bouwpraktijk. Dat dit een relevante vraag is, blijkt ook uit de Kamervragen die begin 2017 zijn gesteld toen de, tot nog toe, laatste versie van het Wetsvoorstel kwaliteitsborging voor het bouwen in de Kamer ter discussie stond. ${ }^{5}$ De structuur van dit artikel is als volgt. In paragraaf 2 wordt beknopt het theoretisch kader van de klachtplicht die voortvloeit uit artikel 6:89 BW behandeld. In paragraaf 3 komen de voorgenomen wijzigingen in het kader van de Wkb aan de orde die betrekking hebben op de aansprakelijkheidspositie van de aannemer na oplevering. Paragraaf 4 analyseert de gevolgen van die wijzigingen voor de toepassing van de klachtplicht in de praktijk, mede in samenhang met de bestaande regels omtrent verjaring en verval. In paragraaf 5 volgt een conclusie, waarbij vanuit het thema van de klachtplicht aansluiting wordt gezocht bij recente ontwikkelingen in het bouwcontractenrecht.

\section{Beknopt theoretisch kader van de klachtplicht uit artikel 6:89 BW}

De wettelijke basis van de klachtplicht is neergelegd in artikel 6:89 BW: 'De schuldeiser kan op een gebrek geen beroep meer doen, indien hij niet binnen bekwame tijd nadat hij het gebrek heeft ontdekt of redelijkerwijs had moeten ontdekken, bij de schuldenaar terzake heeft geprotesteerd.' Uit de parlementaire geschiedenis blijkt dat de klachtplicht is geschreven voor de handelskoop waarbij inspectie bij aflevering plaatsvindt en eventuele klachten meteen worden opgetekend. ${ }^{6},{ }^{7}$ Het begrip 'binnen bekwame tijd'8 uit artikel 6:89 BW lijkt ogenschijnlijk een nogal algemene gedragsnorm, maar het kan grote gevolgen hebben omdat te laat klagen kan meebrengen dat alle vorderingen van de hand worden gewezen. Deze 'alles of niets'-benadering heeft de nodi-

Kamerstukken II 2015/16, 34453, 6, p. 22-23. Zie ook hierna par. 3 MvA II, Parl. Gesch. BW Boek 6 1981, p. 316-317.

De wetgever had dus in eerste instantie fysieke schade aan roerende zaken op het oog. Zie HR 5 april 1968, ECLI:NL:HR 1968, ECLI:NL:HR: 1968:AB6996, NJ 1968/251 (Pekingeenden).

8. Voor een aantal bijzondere overeenkomsten, zoals de koop en aanneming van werk, is deze klachtplicht nader geconcretiseerd. Zo is voor de consumentenkoop in art. 7:23 lid 1 BW geregeld dat de koper er geen beroep meer op kan doen dat hetgeen is afgeleverd niet aan de overeenkomst beantwoordt indien hij de verkoper daarvan niet binnen bekwame tijd nadat hij dit heeft ontdekt of redelijkerwijs had behoren te ontdekken, kennis heeft gegeven. In geval van een consumentenkoop regelt art. 7:23 lid $1 \mathrm{BW}$ in ieder geval dat kennisgeving binnen een termijn van twee maanden na ontdekking tijdig is. ge kritiek gekregen in de literatuur. ${ }^{9}$ De achterliggende gedachte van de klachtplichtregeling is blijkens de wetsgeschiedenis dat de schuldenaar erop moet kunnen rekenen dat de schuldeiser met bekwame spoed onderzoekt of de prestatie beantwoordt aan de verbintenis en dat de schuldeiser, indien dat niet zo blijkt te zijn, dit met spoed aan de schuldenaar meedeelt. ${ }^{10} \mathrm{Na}$ verloop van tijd mag de schuldenaar er gerechtvaardigd op vertrouwen dat de schuldeiser de gebreken heeft aanvaard en ervan afziet zijn recht op herstel uit te oefenen. De schuldenaar wordt met deze regeling beschermd tegen late en daardoor moeilijk te betwisten klachten, waardoor zijn bewijspositie kan worden bemoeilijkt en gebreken kunnen verergeren.

In de literatuur is veel discussie geweest over de toepassing van de klachtplicht in de praktijk. De Hoge Raad heeft daarover in de afgelopen jaren een reeks aan richtinggevende arresten gewezen. Zo verduidelijkte de Hoge Raad in het arrest Pouw/Visser ${ }^{11}$ dat de koper, in andere gevallen dan consumentenkoop, een onderzoeksplicht en een mededelingsplicht heeft jegens de verkoper. Over de lengte van de termijn die is gekoppeld aan de onderzoeksplicht oordeelde de Hoge Raad dat deze afhankelijk is van de omstandigheden, maar dat van de koper de nodige voortvarendheid mag worden verwacht. ${ }^{12}$ Daarbij kan het inschakelen van een deskundige gewenst zijn (hetgeen in de bouwpraktijk frequent aan de orde is). De termijn die staat voor het doen van een mededeling hangt onder meer af van de vraag of de verkoper nadeel lijdt door de lengte van de in acht genomen klachttermijn. In de arresten Ploum/Smeets en Geelen Tankstations I $^{13}$ en II $^{14}$ gaf de Hoge Raad verdere omstandigheden aan ter nadere invulling van het criterium 'binnen bekwame tijd klagen'. Zo overwoog de Hoge Raad dat de termijn van de klacht- en onderzoeksplicht van de koper in samenhang met de omstandigheden van het geval en de aard van de gekochte zaak moet worden beoordeeld. Indien de verkoper geruststellende mededelingen omtrent de eigenschappen van de gekochte zaak doet, mag de koper een uitgebreid onderzoek in eerste instantie achterwege laten. Ook de mate van ingewikkeldheid van het onderzoek is van invloed op de klachttermijn, en in sommige gevallen is medewerking van een derde vereist als de koper zelf niet deskundig genoeg is. In het algemeen is de lijn in de jurisprudentie dat naarmate de koper op grond van de inhoud van de koopovereenkomst en de verdere omstandigheden er sterker op mag vertrouwen dat de zaak beantwoordt aan de overeenkomst, van hem minder snel een (voortvarend) onderzoek mag worden verwacht. ${ }^{15}$ In

9. Zie o.m. C. Bollen \& T. Hartlief, De klachtplicht van de teleurgestelde contractant. Een laatste alles of niets-bolwerk ontmanteld, NJB 2009, p. 2806-2812; W.H. van Boom, Zorgplicht vs. klachtplicht, Ars Aequi 2013/10, p. 755-761; Asser/Van den Berg 7-VI 2017/132a.

10. MvA II, Parl. Gesch. BW Boek 6 1981, p. 316-317.

11. HR 29 juni 2007, ECLI:NL:HR:2007:AZ7617, NJ 2008/606

12. R.o. 3.4.3

13. HR 23 november 2007, ECLI:NL:HR:2007:BB3733, NJ 2008/552.

14. HR 25 maart 2011, ECLI:NL:HR:2011:BP8991, NJ 2013/5.

15. De omstandigheden die daarbij een rol spelen zijn: de aard van het gebrek, de waarneembaarheid van het gebrek, de wijze waarop dit aan 
de 8 februari-arresten ${ }^{16}$ vulde de Hoge Raad aan dat de klachtplicht uit artikel 6:89 BW van toepassing is op alle verbintenissen, waaronder ook die uit beleggingsadviesrelaties. ${ }^{17}$ De Hoge Raad herhaalde in dit arrest de omstandighedencatalogus uit de arresten Pouw/Visser en Ploum/Smeets I en II. Met betrekking tot de omstandigheid dat de schuldenaar geleden nadeel moet hebben om een beroep te kunnen doen op de klachtplicht, werd in het arrest Van de Steeg/Rabobank ${ }^{18}$ verduidelijkt dat de verstreken tijd tussen de bekendheid met het gebrek en het daadwerkelijke protest niet doorslaggevend is voor de vraag of tijdig is geklaagd. ${ }^{19}$

Een specifiek voor de toepassing van de klachtplicht in de bouwpraktijk belangrijk arrest is ABN Amro/Botersloot, ${ }^{20}$ waarin de vraag centraal stond of een koper de aanvang van de klachttermijn kan opschuiven door zich selectief te beroepen op non-conformiteit, namelijk ten aanzien van een bepaald type asbest. De Hoge Raad oordeelde als volgt: '(...) indien de koper later ontdekt dat het gebrek van groter omvang of van andere aard is dan hij eerst dacht, kan aan een beroep op dat gebrek in de weg staan dat hij na zijn aanvankelijke ontdekking geen nader onderzoek heeft gedaan terwijl dat redelijkerwijs wel van hem kon worden verwacht. ${ }^{21}$ Dit arrest rekt de tijd die de koper heeft om te klagen verder op en geeft de koper in de praktijk de gelegenheid om nadere onderzoeken naar de omvang en ernst van het gebrek af te wachten. In het arrest Far Trading/Edco $\mathrm{II}^{22}$ zette de Hoge Raad ten slotte de regels omtrent stelplicht en bewijslast bij een beroep op de klachtplicht, in casu artikel 7:23 BW, op een rij. ${ }^{23}$ De Hoge Raad brengt in dit arrest de klachtplicht expliciet in verband met het leerstuk rechtsverwerking. Uitgangspunt bij toepassing van

het licht treedt, de deskundigheid van de koper, de onderlinge verhouding van partijen, eventueel aanwezige juridische kennis, de behoefte aan voorafgaand deskundig advies, door verkoper gedane mededelingen/geruststellende verklaringen, en de ingewikkeldheid van het onderzoek. Zie W.H. van Boom, Klachtplicht bij koop, Ars Aequi 2011/11, p. 810-814; Asser/Van den Berg 7-VI 2017/132a.

16. O.m. in HR 8 februari 2013, ECLI:NL:HR:2013:BY4600, NJ 2014/497.

17. Zie voor een uitgebreide bespreking van dit arrest Van Boom 2013; J. Hijma, Ontwikkelingen in het overeenkomstenrecht (II), WPNR (2015) 7081, p. 903-909, 908-909.

18. HR 8 februari 2013, ECLI:NL:HR:2013:BY4600, NJ 2014/497.

19. Zie daarover uitgebreid Van Boom 2013, p. 755-761, 760-761, die enerzijds toejuicht dat de Hoge Raad art. 6:89 BW verder deconstrueert, maar anderzijds bepleit om deze deconstructiewerkzaamheden niet ook zonder meer toe te passen op (de hierna te bespreken) contractuele klachtplichten. Indien (professionele) partijen een contractuele regeling treffen die concreter is dan de regeling van de klachtplicht in art. 6:89 BW, moet de 'alles of niets'-sanctionering eerder toelaatbaar worden geacht, aldus Van Boom. Ter onderbouwing wijst hij naar HR 17 februari 2006, ECLI:NL:HR:2006:AU9717, AA 2007/12, p. 358, m.nt. Hartlief (1AA20070358) (Royal \& Sun Alliance/Universal Pictures).

20. HR 9 mei 2014, ECLI:NL:HR:2014:1077, NJ 2014/275

21. R.o. 3.3.3

22. HR 12 december 2014, ECLI:NL:HR:2014:3593.

23. Het voert te ver daar in dit verband verder op in te gaan. Zie voor een uitgebreide analyse van dit arrest F.J.P. Lock, Klachtplicht en bewijslast; is het nu duidelijk?, TVPP 2014/6, p. 167-171; S.J.H. Rutten, Praktijkboek verjarings- en vervaltermijnen in de bouw, Den Haag: IBR 2014, p. 50-51 over de verschillen tussen art. 6:89 en 7:23 BW. de klachtplicht is volgens de Hoge Raad de 'bevrijdend verweer'-gedachte. ${ }^{24}$

\section{Het voorstel Wkb en wijzigingen met betrekking tot de aansprakelijkheid van de aannemer na oplevering}

\subsection{Inleiding}

Voor de aanneming van werk is in titel 7.12 BW een ten opzichte van artikel 6:89 BW nadere concretisering van de klachtplicht opgenomen, namelijk in artikel 7:758 lid $3 \mathrm{BW} .{ }^{25}$ Deze concretisering komt hierna uitvoerig aan bod, mede in het licht van de voorgestelde wijzigingen in het Wetsvoorstel kwaliteitsborging voor het bouwen. Eerst volgt enige toelichting op dit wetsvoorstel.

\subsection{De laatste stand van zaken rondom het voorstel Wkb}

Op 4 juli $2017^{26}$ lag bij de Eerste Kamer het Wetsvoorstel kwaliteitsborging voor het bouwen ter toetsing voor. ${ }^{27}$ Dit wetsvoorstel houdt ingrijpende wijzigingen voor het private en publieke bouwrecht in waarmee de wetgever hoofdzakelijk twee doelstellingen heeft. ${ }^{28}$ Ten eerste de privatisering van het overheidstoezicht op bouwwerken, als gevolg waarvan de overheid meer verantwoordelijkheden neerlegt bij de private partijen en het stelsel van bouw- en woningtoezicht in aanzienlijke mate zal veranderen. ${ }^{29}$ Ten tweede het versterken van de rechtspositie van de (consument-)opdrachtgever ten opzichte van de aannemer. In het Eerste Kamerdebat werden, niet voor het eerst overigens, ${ }^{30}$ diverse bezwa-

24. Vergelijk F.J.P. Lock, Klachtplicht en bewijslast: omzwervingen van de Hoge Raad, TvPP 2015/1, p. 3

25. Uit lid 3 van art. 7:758 BW vloeit geen expliciete klachtplicht voort, maar het bestaan ervan wordt wel aangenomen. Zie ook Jansen, Aanneming van werk (Mon. BW nr. B84), 2013.

26. In 2014 werd begonnen met een internetconsultatie, die na hevige kritiek uit de bouwpraktijk leidde tot een substantieel aangepast wetsvoorstel dat op 21 februari 2017 door de Tweede Kamer is aangenomen. Wetsvoorstel kwaliteitsborging voor het bouwen. Verslag over de binnengekomen reacties, Ministerie van Binnenlandse Zaken en Koninkrijksrelaties 18 mei 2015, www.internetconsultatie.nl/ wetkwaliteitsborgingvoorhetbouwen. Zie Kamerstukken II 2015/16, 32757, 131; Kamerstukken II 2015/16, 34453, 1 e.v.

27. Voluit het Wetsvoorstel wijziging van de Woningwet, de Wet algemene bepalingen omgevingsrecht en het Burgerlijk Wetboek in verband met de invoering van een nieuw stelsel van kwaliteitsborging voor het bouwen en de versterking van de positie van de bouwconsument (Wet kwaliteitsborging voor het bouwen) (34453).

28. Kamerstukken II 2015/16, 34453, 3, p. 2-5

29. Zie uitgebreid Van Gulijk \& Neerhof 2014, deel II.

30. Over de verdeling van verantwoordelijkheden en aansprakelijkheden in bouwprocessen wordt al twintig jaar gediscussieerd in Den Haag. Zie ook Commissie Fundamentele Verkenning Bouw (Commissie Dekker), Privaat wat kan, publiek wat moet. Vertrouwen en verantwoordelijkheid in het bouwproces, Den Haag 2008, i.h.b. p. 4 en 21. Er is overeenstemming over dat zowel de overheid als private partijen hun verantwoordelijkheid voor de kwaliteit van bouwwerken niet waarmaken; er gaat te veel mis en de faalkosten in de bouw zijn te hoog. Zie voor een overzicht van de onderzoeksrapporten die aanleiding hebben gege- 
ren geuit rondom de uitvoerbaarheid van het wetsvoorstel. Op 7 juli 2017 berichtte minister Plasterk de Eerste Kamer dat het kabinet zich nog beraadt op het wetsvoorstel. Op 11 juli 2017 heeft de Eerste Kamer besloten om - zoals verzocht door minister Plasterk - de stemming over het wetsvoorstel uit te stellen. De huidige stand van zaken, op moment van schrijven van dit artikel althans, is dat de wet in ieder geval wordt uitgesteld tot 2019. ${ }^{31}$ Minister Ollongren heeft onlangs de Eerste Kamer verzocht om de behandeling van het wetsvoorstel te hervatten. ${ }^{32}$

\subsection{De huidige regeling omtrent aansprakelijkheid van de aannemer na oplevering}

De laatste versie van het wetsvoorstel (2016) brengt belangrijke privaatrechtelijke wijzigingen mee ten aanzien van de huidige wettelijke regeling van aansprakelijkheid van de aannemer na oplevering. Indien de aannemer te kennen heeft gegeven dat het werk klaar is om te worden opgeleverd, zal het werk doorgaans door de opdrachtgever worden gekeurd en (al dan niet stilzwijgend) aanvaard. ${ }^{33} \mathrm{Na}$ de aanvaarding van het werk wordt het als opgeleverd beschouwd. Die oplevering is niet alleen voor de opdrachtgever, maar ook voor de aannemer een belangrijk moment, want zij brengt een verschuiving van het risico voor het werk mee (art. 7:758 lid 2 BW). ${ }^{34}$ Artikel 7:758 lid 3 BW regelt namelijk dat de aannemer, vanaf het moment van oplevering, niet langer aansprakelijk is voor gebreken die de opdrachtgever op het tijdstip van oplevering redelijkerwijs had moeten ontdekken. ${ }^{35}$ Dit artikellid geeft een ten opzichte van artikel 6:89 $\mathrm{BW}$ bijzondere regel met betrekking tot het leerstuk van de rechtsverwerking. ${ }^{36}$ De uit artikel 6:89 BW voortvloeiende onderzoeksplicht ${ }^{37}$ van de opdrachtgever wordt in artikel 7:758 lid 3 BW beperkt tot gebreken die hij op het tijdstip van oplevering heeft ontdekt of redelijkermijze had moeten ont-

ven tot het wetsvoorstel o.a. Van Gulijk \& Neerhof 2014, p. 1-2, 10-12, 237-238, 245-246.

31. Zie de berichtgeving hierover door het Instituut voor Bouwkwaliteit op www.stichtingibk.nl/2017/07/11/reacties-op-uitstel-wetkwaliteitsborging/.

32. Zie de brief van minister Ollongren aan de Eerste Kamer van 29 juni 2018, Afschriftbrief over het wetsvoorstel Kwaliteitsborging voor het bouwen, te raadplegen via www.rijksoverheid.nl/ministeries/ministerievan-binnenlandse-zaken-en-koninkrijksrelaties/documenten/brieven/ 2018/06/29/afschriftbrief-over-wetsvoorstel-kwaliteitsborging-voor-het -bouwen.

33. Zie daarover art. 7:758 lid 1 BW. Het voorstel Wkb introduceert voor de aannemer de verplichting om bij de oplevering een overdrachtsdossier aan de opdrachtgever te overhandigen. Zie daarover bijv. E.M. Bruggeman \& H.P.C.W. Strang, Wet Kwaliteitsborging behandeld in Tweede Kamer, TBR 2017/52, p. 1-3; S. van Gulijk \& A.R. Neerhof, Kwaliteitsborging voor het bouwen 2.0: nog steeds geen licht aan het einde van de tunnel, TBR 2017/143, p. 957-966.

34. Zie uitgebreid Asser/Van den Berg 7-VI 2017/126 e.v.

35. Als zich na de oplevering gebreken voordoen waarvoor de aannemer aansprakelijk is, regelt art. 7:759 lid 1 BW dat de opdrachtgever de aannemer in de gelegenheid moet stellen om de gebreken te herstellen.

36. Asser/Van den Berg 7-VI 2017/113.

37. Volgens Van den Berg gaat het hier om een door rechtsverlies gesanctioneerde gehoudenheid tot het doen van onderzoek naar gebreken. Zie Asser/Van den Berg 7-VI 2017/113. dekken. Met betrekking tot die gebreken dient de opdrachtgever dan binnen bekwame tijd te klagen bij de aannemer. Bij de toepassing van deze aansprakelijkheidsregeling in de praktijk doet zich het probleem voor dat de aanwezige deskundigheid van de opdrachtgever een bepalende rol speelt. ${ }^{38}$ Indien de aannemer door de opdrachtgever na oplevering wordt aangesproken voor gebreken, kan de aannemer onder de huidige regeling het verweer voeren dat deze opdrachtgever, gezien zijn aanwezige deskundigheid, het gebrek had moeten onderkennen bij de oplevering. Nu hij dat niet heeft gedaan, heeft de opdrachtgever geen aanspraak meer op de aannemer. Zijn recht is verwerkt. De nadere concretisering van artikel 6:89 $\mathrm{BW}$ in artikel 7:758 lid $3 \mathrm{BW}$ is daarmee in de praktijk vaak in het nadeel van de opdrachtgever. Dit is in de literatuur als een onwenselijke situatie aangemerkt, omdat de aansprakelijkheid van de aannemer hierdoor afhangt van de vraag of een opdrachtgever het gebrek al dan niet heeft ontdekt bij de oplevering. ${ }^{39}$ Terwijl de aannemer doorgaans de deskundige partij is, die beter dan de opdrachtgever op de hoogte zal zijn van eventuele gebreken in het werk. ${ }^{40}$

\subsection{Het voorgestelde nieuwe lid 4}

Het komt dan ook niet als een verrassing dat in het wetsvoorstel aan deze aansprakelijkheidsregeling is gesleuteld. In eerdere versies van het wetsvoorstel is getracht lid 3 van artikel 7:758 $\mathrm{BW}$ te herformuleren, maar daarvoor was te weinig steun. ${ }^{41}$ In het nu voorliggende wetsvoorstel wordt lid 3 volledig in tact gelaten en een nieuw lid 4 toegevoegd dat alleen geldt voor aanneming van boumwerken. ${ }^{42}$ De titel 'aanneming van werk' is immers niet beperkt tot bouwactiviteiten, maar omvat ook andere verrichtingen van stoffelijke aard, zoals het repareren van roerende zaken als auto's, fietsen, klokken of sieraden en het stomen van kleding. ${ }^{43}$ Het nieuwe lid 4 betreft dus alleen aanneming van boumwerken en komt als volgt te luiden:

'In afwijking van het derde lid, is bij aanneming van bouwwerken de aannemer aansprakelijk voor gebreken die bij de oplevering van het werk niet zijn ont-

38. Zie ook MvT, Kamerstukken II 1992/93, 23095, 3, p. 38

39. Zie o.m. M.A.B. Chao-Duivis \& H.P.C.W. Strang, Naar een andere verdeling van verantwoordelijkheid in de bouw, Onderzoek naar privaatrechtelijke verbeteringsmogelijkheden van de bouwkwaliteit, Den Haag: Instituut voor Bouwrecht 2013.

40. Zie eveneens Asser/Van den Berg 7-VI 2017/110-119; M.A.B. ChaoDuivis, Verwarring en verwatering bij wetsvoorstel Kwaliteitsborging, TBR 2017/36, p. 198-200.

41. Zie o.m. E.C. Brinkman, Reactie Bouwend Nederland op 'Certificering en normalisatie in het publieke bouwrecht' en 'Naar een andere verdeling van verantwoordelijkheid in de bouw', TBR 2014/94, p. 506-508; L.C van den Berg, Naar een andere verdeling van verantwoordelijkheid in de bouw, TBR 2014/95, p. 509-513; P. Vermeij, Enkele kritische opmerkingen over het (eind)rapport 'Naar een andere verdeling van verantwoordelijkheid in de bouw', TBR 2014/98, p. 518-528.

42. Overigens zijn daarover in de Eerste Kamer vragen gesteld: 'Wat rechtvaardigt dat specifiek bij de aanneming van bouwwerken regels worden gesteld die ten nadele van de aannemer afwijken ten opzichte van wat geldt bij de aanneming van werk dat niet leidt tot een bouwwerk?', Kamerstukken I 2016/17, 34453, B, p. 8.

43. Vergelijk Asser/Van den Berg 7-VI, 2017/73. 
dekt, tenzij deze gebreken niet aan de aannemer zijn toe te rekenen. Van dit lid kan niet ten nadele van de opdrachtgever worden afgeweken, voor zover de opdrachtgever een natuurlijk persoon is die niet handelt in de uitoefening van een beroep of bedrijf. In andere gevallen kan van dit lid alleen ten nadele van de opdrachtgever worden afgeweken, indien dit uitdrukkelijk in de overeenkomst is opgenomen.'

Als het wetsvoorstel wordt aangenomen, is de aannemer op grond van het voorgestelde lid 4 aansprakelijk voor gebreken die bij de oplevering feitelijk niet zijn ontdekt, tenzij hij bewijst dat die gebreken niet aan hem zijn toe te rekenen. De wetgever introduceert hiermee een nieuw, feitelijk criterium ('niet zijn ontdekt') voor de aansprakelijkheid van de aannemer na oplevering. Bewijsrechtelijk betekent dit dat het risico van de bewijsvoering (dat het gebrek niet aan hem is toe te rekenen) bij de aannemer komt te liggen. ${ }^{44}$ De juridische positie van de consument-opdrachtgever ten opzichte van de aannemer wordt hiermee aanzienlijk versterkt nu niet ten nadele van die consumentopdrachtgever van lid 4 kan worden afgeweken. Afwijken kan slechts indien een professionele opdrachtgever de wederpartij is, mits in onderling overleg én de afwijking uitdrukkelijk is overeengekomen in de aannemingsovereenkomst. ${ }^{45}$

\section{Gevolgen van het nieuwe lid 4 voor toepassing van de klachtplicht in de praktijk}

\subsection{De voorgestelde aansprakelijkheidsregeling kritisch beschouwd}

Zoals reeds aan de orde kwam, wordt met het wetsvoorstel een nieuw feitelijk criterium geintroduceerd in artikel 7:758 lid 4 BW: 'gebreken die niet zijn ontdekt'. Enerzijds strookt dit criterium met de regelingen voor aansprakelijkheid van de aannemer in algemene voorwaarden voor de (bouw)contractspraktijk, ${ }^{46}$ wat duidelijkheid voor contractspartijen geeft. ${ }^{47}$ Anderzijds wordt met dit feitelijk criterium nog verder afgeweken van de klachtplichtregeling in artikel 6:89 $\mathrm{BW}$ dan het geval is onder artikel 7:758 lid $3 \mathrm{BW}$. Hierover zijn zowel door

44. Bij de behandeling in de Eerste Kamer is gesproken over een 'vooronderstelde aansprakelijkheid van de aannemer, met mogelijkheid van tegenbewijs'. In het contractenrecht komt een dergelijke vooronderstelde aansprakelijkheid bij hoge uitzondering terug, bijvoorbeeld ten behoeve van consumentenbescherming.

45. Een verwijzing naar algemene voorwaarden is daarvoor niet voldoende, aldus de minister.

46. Zoals de UAV-gc 2001. Met deze voorgenomen wijzigingen schuift de titel 'aanneming van werk' overigens ook meer op richting de in het kader van Europese eenwording van het contractenrecht tot stand gebrachte PEL SC en CFR.

47. Asser/Van den Berg 7-VI, 2017/113 de bouwpraktijk zelf ${ }^{48}$ als tijdens het Kamerdebat vragen gesteld. ${ }^{49}$ Op zichzelf wijzigt het voorgestelde lid 4 niets aan de klachtplicht die voortvloeit uit artikel 6:89 BW. Die klachtplicht blijft bestaan. Wanneer de opdrachtgever niet tijdig klaagt over gebreken die door hem feitelijk zijn ontdekt, verliest hij zijn rechten. Dit rechtsverlies wordt met lid 4 echter wel fors beperkt tot feitelijke ontdekkingen bij oplevering. Terwijl onder het huidige artikel 7:758 lid 3 BW ook gebreken die de opdrachtgever bij de oplevering redelijkermijs had moeten ontdekken, maar waartegen hij bij de aannemer niet tijdig protesteerde, rechtsverlies opleveren. ${ }^{50}$ Gebreken die de opdrachtgever niet heeft ontdekt maar redelijkerwijs wel had moeten ontdekken, ontslaan de aannemer niet langer van zijn aansprakelijkheid. ${ }^{51}$

De discussie omtrent aansprakelijkheid van de aannemer voor verborgen gebreken verplaatst zich nu naar artikel 6:89 BW. Hoewel aannemers de opdrachtgever in het nieuwe voorstel niet meer kunnen tegenwerpen dat deze dermate deskundig was dat hij het gebrek had moeten onderkennen bij de oplevering, kunnen zij de opdrachtgever op basis van artikel 6:89 BW blijven tegenwerpen dat te laat is geklaagd. In dat geval staat de opdrachtgever wegens rechtsverlies alsnog met lege handen. De leden van de SGP-fractie legden ook de vinger op deze zere plek en vroegen aan de minister: '(...) hoe de regering kan stellen dat een evenwichtiger aansprakelijkheidsverdeling ontstaat nu zij in het voorstel expliciet de achterliggende gedachte achter de huidige aansprakelijkheidsverdeling continueert, zoals uitgewerkt in artikel 6:89 BW' ${ }^{52}$ De minister heeft met het voorgestelde lid 4 de hiervoor uiteengezette discussie rondom de aansprakelijkheid voor verborgen gebreken willen verleggen van de deskundigheid van de opdrachtgever naar de toerekening van het gebrek aan de aannemer, zo is te lezen in de memorie van toelichting. ${ }^{53}$ Een van de achterliggende overwegingen hierbij is dat het in de praktijk vaak gaat om een opdrachtgever die niet de kennis en/of mogelijkheden heeft om te beoordelen of er sprake is van een gebrek en wie daarvoor verantwoordelijk is. Dit terwijl de aannemer die kennis wel heeft of in elk geval wordt geacht te hebben. ${ }^{54}$ De minister lijkt hier in een cirkel te redeneren. De nieuwe aansprakelijkheidsregeling is enerzijds nodig omdat als gevolg van de huidige regeling de deskundigheid van de opdrachtgever een te

48. Zie bijv. D. van Werven, Verwarring zonder nuancering, TBR 2017/51, p. 270-272.

49. Er is ook andere kritiek geuit op de voorgestelde privaatrechtelijke wijzigingen van de aansprakelijkheid van de aannemer. Bijvoorbeeld over het in het wetsvoorstel gebruikte begrip opdrachtgever, dat voor veel onduidelijkheid zorgt. Zie Van Gulijk \& Neerhof 2015; Chao-Duivis 2017; Van Werven 2017. In de Tweede Kamer werd aangedrongen op meer differentiatie tussen de verschillende typen opdrachtgevers in de bouw, maar de minister vindt een wettelijk onderscheid tussen meer en minder professionele partijen te ingewikkeld en onnodig. Zie Handelingen II 2016/17, 41, item 7, p, 26; Kamerstukken II 2015/16, 34453, 6, p. 22-23.

50. Vergelijk Asser/Van den Berg 7-VI 2017/113.

51. Zie ook Asser/Van den Berg 7-VI 2017/113.

52. Kamerstukken II 2015/16, 34453, 6, p. 22-23

53. Zie MvT, Kamerstukken II 2015/16, 34453, 3, p. 34-35.

54. Zie MvT, Kamerstukken II 2015/16, 34453, 3, p. 34-35. 
grote rol speelt bij het bepalen van de aansprakelijkheid van de aannemer voor verborgen gebreken, terwijl anderzijds een effect van het wetsvoorstel is dat vooral de ondeskundige opdrachtgever beschermd wordt. Maar in het geval van een ondeskundige opdrachtgever speelt voornoemde discussie omtrent de deskundigheid van de opdrachtgever bij oplevering nauwelijks, want dan zal de aannemer doorgaans niet wegkomen met het verweer dat de opdrachtgever het gebrek had moeten onderkennen bij de oplevering. De wetgever heeft met het voorstel vooral de consument-opdrachtgever een sterkere procesrechtelijke positie gegeven. ${ }^{55}$ Dat sluit overigens wel aan bij het inzicht dat artikel 7:758 lid $3 \mathrm{BW}$ niet zozeer een materieelrechtelijke, maar vooral een bewijsrechtelijke functie zou hebben. ${ }^{56}$

\subsection{De klachtplicht in samenhang met verjaring en verval bij aanneming van werk}

De klachtplicht staat niet op zichzelf, maar verhoudt zich in belangrijke mate tot de regels omtrent verjaring en verval. In Boek $3 \mathrm{BW}$ zijn verschillende voor de bouwpraktijk relevante algemene verjaringstermijnen opgenomen, te weten in de artikelen 3:306, 3:307, 3:310 lid 1 en 2 en 3:311 lid 1 BW. ${ }^{57}$ Deze houden, kort gezegd, voor rechtsvorderingen een verjaringstermijn van vijf jaar in vanaf het moment dat de benadeelde zowel met de schade of de opeisbaarheid van de boete als met de daarvoor aansprakelijke persoon bekend is geworden, en in ieder geval door verloop van twintig jaar na de gebeurtenis waardoor de schade is veroorzaakt. Specifiek voor de koop en aanneming van werk zijn in Boek 7 BW afwijkende verjaringstermijnen opgenomen. Voor de koopovereenkomst vloeit uit artikel 7:23 lid $2 \mathrm{BW}$ een verjaringstermijn van twee jaar voort die aanvangt na ontvangst van de kennisgeving van nonconformiteit van de koper als bedoeld in lid $1 .{ }^{58}$ Voor de aannemingsovereenkomst regelt artikel 7:761 lid $1 \mathrm{BW}$ analoog aan artikel 7:23 BW dat vanaf het moment dat het bouwwerk is opgeleverd een tweejarige verjaringstermijn gaat lopen nadat de opdrachtgever heeft geprotesteerd wegens een gebrek in het opgeleverde werk. ${ }^{59}$ Volgens lid 2 van dat artikel verjaart de rechtsvordering in ieder geval door verloop van twintig jaar (een absolute verjaringstermijn) na de oplevering in geval van aanneming van bouwwerken, en door verloop van tien jaar na de oplevering in alle andere gevallen. Deze termijn begint te lopen vanaf de aanvaarding ${ }^{60}$ van het werk door de opdrachtgever en ziet derhalve op verborgen

55. Zie ook eerder in Van Gulijk \& Neerhof 2017, p. 963-965.

56. Vergelijk M.A.B. Chao-Duivis, Aansprakelijkheid van de aannemer na de oplevering, TBR 2015/19, p. 112-114; M.A.B. Chao-Duivis, Nogmaals: naar een andere regeling van de aansprakelijkheid na oplevering, exit het onderscheid verborgen en niet-verborgen gebreken, TBR 2016/80, p. 519-520. Overigens blijkt die bescherming van de juridische status van de consument-opdrachtgever ook uit het feit dat het voorgestelde lid 4 dwingendrechtelijk is. Zie MvT, Kamerstukken II 2015/16, 34453, 3, p. 3, 36, 91.

57. Zie hierover uitgebreid Rutten 2014, p. 27-36

58. Conform art. 3:37 lid 3 BW.

59. Zie over de ratio van dit wetsartikel Jansen 2013

60. Op art. 7:761 BW kan geen beroep worden gedaan als het werk nog niet is aanvaard door de opdrachtgever. gebreken. Artikel 7:761 BW bevat dus een wettelijke, dubbele verjaringstermijn. ${ }^{61}$

De hiervoor besproken klachtplicht houdt nauw verband met de problematiek van verjaring en verval. Vanaf het moment dat door de opdrachtgever wordt geprotesteerd bij de aannemer wegens een gebrek aan het werk, gaat de uit artikel 7:761 lid $1 \mathrm{BW}$ voortvloeiende verjaringstermijn lopen. Dat dwingt de opdrachtgever om in actie te (blijven) komen en op herstel van de gebreken aan te dringen bij de aannemer, dan wel de verjaringstermijn te stuiten. Aan de verjaringsregels komt men echter niet toe indien de opdrachtgever niet (tijdig) heeft geklaagd wegens een gebrek. Het niet voldoen aan de klachtplicht levert in dat geval een doorkruising van de verjaring op. ${ }^{62}$ Anders geformuleerd: aan toepassing van de korte tweejaarstermijn uit artikel 7:761 lid 1 BW kan niet worden toegekomen als de opdrachtgever zijn rechten en bevoegdheden uit hoofde van artikel 6:89 $\mathrm{BW}$ al heeft verloren omdat hij niet binnen bekwame tijd heeft geprotesteerd bij de aannemer. Overigens kan het criterium 'binnen bekwame tijd' in de bouwpraktijk nogal een lange periode meebrengen, omdat de opdrachtgever er doorgaans een deskundige derde bij zal moeten halen voor onderzoek. In dat geval wordt de verjaringstermijn op grond van artikel 7:761 lid $3 \mathrm{BW}$ verlengd met zes maanden. ${ }^{63}$

Partijen kunnen in afwijking van de wettelijke verjaringstermijnen een contractuele verval- of garantietermijn opnemen in de overeenkomst. ${ }^{64} \mathrm{Zo}$ is in paragraaf 12.4 van de UAV 2012 een processuele vervaltermijn voor verborgen gebreken opgenomen. Uitgangspunt van die regeling is verval van de rechtsvordering, uit hoofde van een gebrek waarvoor de aannemer op grond van voornoemde regel aansprakelijk is, na verloop van vijf jaar na de dag van oplevering. Indien echter sprake is van een ernstig gebrek ${ }^{65}$ geldt een vervaltermijn van tien jaar na de dag van oplevering. Vervaltermijnen zijn in tegenstelling tot verjaringstermijnen niet vatbaar voor stuiting. ${ }^{66}$ De tweejarige wettelijke verjaringstermijn uit artikel 7:761 lid $1 \mathrm{BW}$ kan deze procesrechtelijke vervaltermijn uit de UAV 2012 doorkruisen. ${ }^{67}$ Anderzijds kan de vervaltermijn uit de UAV 2012 de twintigjarige verjaringstermijn uit artikel 7:761 lid 2 BW weer doorkruisen. Immers, aan het einde van de vervaltermijn is de opdrachtgever zijn rechtsvordering kwijt. ${ }^{68}$ In paragraaf 12.2 van de UAV 2012 is voorts een onderzoeks-

61. Rutten 2014, p. 39

62. Asser/Van den Berg 7-VI 2017/132a

63. Zie ook art. 7:759 lid 2 BW, waarin een termijnstelling voor het wegnemen van het gebrek is opgenomen.

64. Asser/Van den Berg 7-VI 2017/132b

65. Een ernstig gebrek is aan de orde indien het werk geheel of gedeeltelijk is ingestort of dreigt in te storten, dan wel ongeschikt is geraakt of ongeschikt dreigt te geraken voor de bestemming waarvoor het blijkens de overeenkomst bedoeld is en dit slechts kan worden verholpen of kan worden voorkomen door het treffen van zeer kostbare voorzieningen.

66. Een opdrachtgever moet derhalve binnen de vervaltermijn een rechtsvordering instellen. Zie Rutten 2014, p. 41; M.A. Van Wijngaarden \& M.A.B. Chao-Duivis, Bouw- en Aanbestedingsrecht, deel 2, 2014), p. 77 e.v. voor een rechtspraakoverzicht.

67. Asser/Van den Berg 7-VI 2017/132b.

68. Zie ook Rutten 2014, p. 41. 
plicht van de opdrachtgever neergelegd: de aannemer is na oplevering ontslagen van aansprakelijkheid tenzij '(a) het gebrek is toe te rekenen aan de aannemer, (b) het gebrek bovendien ondanks nauwlettend toezicht (...) redelijkerwijs niet onderkend had kunnen worden en waarvan (c) de aannemer binnen een redelijke termijn na de ontdekking mededeling is gedaan'. Het verzaken van de onderzoeksplicht die hieruit voortvloeit brengt voor de opdrachtgever volledig rechtsverlies mee. ${ }^{69}$

Hoe verhoudt deze regeling in paragraaf 12 van de UAV 2012 zich nu tot het voorgestelde artikel 7:758 lid 4 BW? De kloof tussen de UAV 2012 en de wettelijke regeling wordt groter. Immers, uit hoofde van het voorgestelde lid 4 heeft de opdrachtgever op het moment van oplevering geen enkele onderzoeksplicht meer. Dit staat haaks op de UAV-regeling. Uiteraard dient hij nog altijd binnen bekwame tijd nadat hij het gebrek heeft ontdekt te protesteren bij de aannemer, maar er is alleen dan sprake van rechtsverlies aan de zijde van de opdrachtgever als hij het gebrek ook daadwerkelijk heeft ontdekt en daartegen niet heeft geprotesteerd. De klachtplicht uit artikel 6:89 BW wordt des te belangrijker voor de bouwpraktijk. Bovendien, wanneer het gaat om consumentenopdrachtgevers zijn de UAV 2012 in strijd met het dwingende karakter van het voorgestelde lid $4 .^{70}$ Voor alle andere opdrachtgevers dan consumenten, het merendeel van de gebruikers van de UAV 2012, die de UAV-regeling met betrekking tot de aansprakelijkheid na oplevering prevaleren boven de wettelijke regeling, zal gelden dat zij in onderling overleg met de aannemer in de overeenkomst zelf een afwijkende regeling zullen moeten opnemen.

\section{Conclusie}

Over de verdere ontwikkeling van het Wetsvoorstel kwaliteitsborging voor het bouwen wordt momenteel door de verantwoordelijke minister nagedacht. Gemeenten, eigenwoningbezitters en bouwers stuurden onlangs een brandbrief aan de minister waarin zij over het wetsvoorstel zoals het er nu ligt het volgende aangaven: 'te duur, te ingewikkeld en volstrekt onduidelijk of de bouwkwaliteit verbetert'. ${ }^{71}$ De minister is nu aan zet. Uit deze bijdrage vloeit voort dat het wetsvoorstel ook ten aanzien van de aansprakelijkheid van de aannemer in relatie tot de klachtplichtregeling nogal te wensen overlaat. Zo is te verwachten dat de discussie rondom de aansprakelijkheid voor verborgen gebreken (betreffende de huidige aansprakelijkheidsregeling) zich zal verleggen naar discussies omtrent de vraag of door de opdrachtgever tijdig is geklaagd ex artikel 6:89 BW. Daarmee zou deze regeling in de praktijk juist tot een toename aan geschillen kunnen leiden. Zo zouden

69. Asser/Van den Berg 7-VI 2017/132b.

70. Ook zo Asser/Van den Berg 7-VI 2017/113

71. Deze brief is online te raadplegen via www.cobouw.nl/bouwbreed/ nieuws/2018/05/brandbrief-aan-minister-pas-wet-kwaliteitsborgingbouw-op-drie-onderdelen-aan-101261027. partijen in voorkomende gevallen van mening kunnen verschillen over het moment waarop de opdrachtgever het gebrek had kunnen ontdekken en bij de aannemer had moeten klagen. De concrete omstandigheden die moeten worden afgewogen om te bepalen of de opdrachtgever tijdig heeft geklaagd bij de aannemer, gaan een (nog) grotere rol spelen als de Wkb wordt ingevoerd. Factoren die daarbij een belangrijke rol zullen gaan spelen zijn, gelet op de in paragraaf 3 genoemde, uit de jurisprudentie afkomstige omstandigheden, de deskundigheid van de opdrachtgever, de aard van het gebrek en de te verwachten of al ontstane schade. Vermoedelijk wordt een niet-deskundige opdrachtgever voor bij de oplevering zichtbare gebreken een vrij ruime klachttermijn op basis van artikel 6:89 BW gegund. Voor de aannemer betekent dit dat hij de stand van het gebouwde op het moment van oplevering zeer nauwkeurig zal moeten (laten) vastleggen in het proces-verbaal van oplevering, bij voorkeur door middel van eerdergenoemde digitale tools. De verhoudingen worden op scherp gezet. Hoewel vooral de particuliere opdrachtgever er een (door de minister ook beoogde) sterkere juridische positie door krijgt ten opzichte van de aannemer, is het nog maar de vraag wat het wetsvoorstel precies gaat opleveren voor de bouwkwaliteit. ${ }^{72}$
72. Vergelijk Van Gulijk \& Neerhof 2017; S. van Gulijk, Construction Quality Improvement: a comparative overview and discussion of the role of insurance in assuring construction quality and safety, International Construction Law Review 2018/4. 